\title{
Does Indonesia's Economic Growth Reduce Unemployment?
}

\author{
Dwi Windu Suryono*, Agustian Burda, Rama Chandra \\ Department of Management \\ Sekolah Tinggi Ilmu Ekonomi Indonesia \\ Jakarta, Indonesia \\ *dwiwindu1961@stei.ac.id
}

\begin{abstract}
This study is aimed at examining the existence of Okun's law, the negative relationship between economic growth and unemployment using First Difference Model to secondary data on real Gross Domestic Product and the open unemployment rate of Indonesia during the period 1986 - 2018. Okun's law exist in the Indonesia's economy. Economic growth during 1986-2018 was able to reduce the number of unemployed people in Indonesia.
\end{abstract}

Keywords: Okun's law, economic growth, unemployment, First Difference Model

\section{INTRODUCTION}

Since 2014 Indonesia's economic growth has been said to be stable at around five percent. Stability on macro indicators has no impact to spur economic movement or growth. Though new employment is needed to absorb labour from a large population. This illustrates that the prerequisites for macroeconomic stability are not optimized to be able to accelerate growth and reduce poverty, unemployment, and income inequality [1].

The strategy of pursuing economic growth in an effort to reduce unemployment is based on Okun's law. He revealed there were indications of a negative relationship between economic growth, the gap in real output with potential output and unemployment. Okun stated that a one percent reduction in unemployment would increase output by around three percent [2]. Therefore to avoid unemployment, the economy must continue to develop. Over a period of more than thirty years, some economists found strong empirical order in the relationship, and became an important rationale in the macroeconomic framework [3].

The study of the existence of the Okun law in Indonesia is important, because so far it has been used as the basis for a strategy to pursue economic growth to reduce unemployment. In addition, the Okun coefficient can be a reference to the target number of unemployment and is the basis for evaluating actual economic growth achievements compared to its potential level [4].

\section{THEORETICAL FRAMEWORK}

Okun's Law postulates a negative relationship between the unemployment rate and the real Gross Domestic Product
(GDP). This empirical relationship is a major part of every traditional macro model. In his article Okun empirically presents several relationships [5].

First, the first difference regression of the unemployment rate $(\mathrm{U})$ to the percentage change in output $(\mathrm{Y})$, using quarterly data for the period 1947-1960, had result:

$$
\Delta \mathrm{u}=0.3-0.3 \Delta \mathrm{Y} / \mathrm{Y}
$$

If there is no economic growth, the unemployment rate will increase by 0.3 every quarter. Economic growth is needed one percent per quarter or four percent per year so that the unemployment rate does not increase or decrease.

Second, it regresses the unemployment rate to the output gap, using quarterly data for the period 1953-1960, and the results are obtained:

$$
\mathrm{U}=3.72+0.36 \mathrm{gap}
$$

This result implies that every one percent increase in unemployment associated with the economy will lose output 3.6 percent of its potential level. Even though there is no output gap, unemployment remains at 3.72 percent.

Third, estimating the elasticity of output to the level of employment:

$$
\left(Y^{*}-Y\right) / Y=0.032(U-4)
$$

The coefficient of 0.032 can be interpreted that every one percent decrease in unemployment will increase output by approximately three percent, so that actual output is getting closer to its potential level or it can be stated that the output gap will become more isolated in line with the decline in unemployment. The coefficient is then known as the Okun coefficient.

Okun's coefficient interpretation shows the magnitude of changes in the unemployment rate as a result of one percent changes in economic growth [6]. Okun coefficient is one of the important components that economists study in analysing Okun's law for several reasons [4]. First, if the unemployment rate is a policy variable, then the Okun coefficient can be interpreted as the magnitude of the economic target to reduce the unemployment rate. Second, forecasting output is often made to express forecasting of the unemployment rate. Third, 
Decomposition Variance (FEDV) techniques are used to predict the percentage of variance for each variable due to changes in certain variables in the VAR system. The results showed a negative relationship between economic growth and changes in unemployment as Okun revealed, based on the results of Scatter Plot and regression. In addition, based on the results of the FEVD output it appears that an important source of variation in unemployment is shocks from unemployment itself [10].

\section{METHODS}

To examine the existence of Okun's law in Indonesia, the model specifications used:

\section{A. First Difference Model}

$$
\begin{aligned}
& Y_{\mathrm{t}}-Y_{\mathrm{t}-1}=\alpha+\beta\left(U N P_{\mathrm{t}}-U N P_{\mathrm{t}-1}\right)+\varepsilon_{\mathrm{t}} \\
& \Delta Y_{\mathrm{t}}=\alpha+\beta \Delta U N P_{\mathrm{t}}+\varepsilon_{\mathrm{t}}
\end{aligned}
$$

$$
\begin{array}{ll}
Y t & : \text { Real GDP of a certain year } \\
Y t-1 & : \text { Previous year's real GDP } \\
U N P t & : \text { Unemployment of a certain year } \\
U N P t-1 & : \text { Unemployment of the previous year }
\end{array}
$$

\section{B. Unit Root Testing}

Stationarity is very much needed in time series analysis so that spurious analysis does not occur. Because in the research period there were two shock crises, the Philip-Perron test to check the stability and the respond to the shock, was used. The procedure for unit root testing using the Philips- Perron test is as follows:

$$
\begin{gathered}
f_{\alpha}=t_{\alpha}\left(\frac{\gamma_{0}}{f_{0}}\right)^{1 / 2}-\frac{\left(f_{0}-\gamma_{0}\right) \operatorname{se}(\hat{\alpha})}{f_{0}^{1 / 2} s} \\
t_{\alpha}=\frac{\hat{\alpha}}{\operatorname{se}(\hat{\alpha})}
\end{gathered}
$$

Se $(\alpha)$ is the standard error of the coefficient $y t-1$ and $\mathrm{s}$ is the standard error of equation (3.4). $\gamma 0$ is a consistent estimate of the error variance in equation (3.4). The Philips-Perron statistical value, which is $t \alpha$ compared to the Mc Kinnon table's critical value. If the Philips-Perron statistical value is more negative than the Mc Kinnon table's critical value or the Philips-Perron statistical probability value is less than the significance level $(\alpha)$ of 0.05 ; then Ho is rejected so it can be concluded that the time series data has been stationary.

\section{RESULTS}

The data used in this study are real GDP data (base year 2010) and open unemployment rate (UNP) in the period 1986 2018, sourced from the Indonesian Central Statistics Agency (Biro Pusat Statistik). Real GDP and UNP data are transformed by natural logarithms. 
TABLE I. STATIONARITY TEST RESULt

\begin{tabular}{|c|c|c|c|c|c|c|}
\hline \multirow{3}{*}{$\begin{array}{c}\text { Variable } \\
\quad s\end{array}$} & \multicolumn{6}{|c|}{ Philip Pherron Test } \\
\hline & \multicolumn{2}{|c|}{ None } & \multicolumn{2}{|c|}{ Individual Effect } & \multicolumn{2}{|c|}{$\begin{array}{c}\text { Individual and } \\
\text { Linier Effect }\end{array}$} \\
\hline & Tstat & Prob & Tstat & Prob. & Tstat & Prob \\
\hline UNP & 0.04210 & 0.9792 & 2.02806 & $\begin{array}{l}0.362 \\
8\end{array}$ & $\begin{array}{l}0.3326 \\
1\end{array}$ & $\begin{array}{l}0.982 \\
7\end{array}$ \\
\hline GDP & 4.18984 & 0.9999 & 2.38154 & $\begin{array}{l}0.999 \\
9\end{array}$ & $\begin{array}{l}2.2630 \\
3\end{array}$ & $\begin{array}{l}0.861 \\
7\end{array}$ \\
\hline $\mathrm{D}$ (UNP) & 331.028 & 0.0000 & 95.6247 & $\begin{array}{l}0.000 \\
0\end{array}$ & $\begin{array}{l}52.606 \\
7\end{array}$ & $\begin{array}{l}0.000 \\
0\end{array}$ \\
\hline $\mathrm{D}$ (GDP) & -168656 & 0.0000 & -9.12931 & $\begin{array}{l}0.000 \\
0\end{array}$ & $\begin{array}{l}- \\
6.4323 \\
4\end{array}$ & $\begin{array}{l}0.000 \\
1\end{array}$ \\
\hline
\end{tabular}

Based on the results of the Phillip-Perron test, both real GDP and UNP data in level as well as in integrated logarithmic transformation in first order or have been stationary in the form of first difference.

TABLE II. FIRST DIFFERENCE MODEL RESUlT

\begin{tabular}{|c|c|c|c|c|}
\hline Variable & Coefficient & Std. Error & t-Statistic & Prob. \\
\hline $\mathrm{D}(\mathrm{UNP}) \mathrm{C}$ & $\begin{array}{l}-0.188121 \\
0.020501\end{array}$ & $\begin{array}{l}0.057055 \\
0.005358\end{array}$ & $\begin{array}{l}-3297171 \\
3.826043\end{array}$ & $\begin{array}{l}0.0016 \\
0.0003\end{array}$ \\
\hline R-squared & 0.147166 & \multicolumn{2}{|c|}{ Mean dependent var } & 0.016558 \\
\hline $\begin{array}{l}\text { Adjusted R- } \\
\text { squared }\end{array}$ & 0.133629 & \multicolumn{2}{|c|}{ S.D. dependent var } & 0.045241 \\
\hline $\begin{array}{l}\text { S.E. of } \\
\text { regression }\end{array}$ & 0.042110 & \multicolumn{2}{|c|}{ Akaike info criterion } & -3.466780 \\
\hline $\begin{array}{l}\text { Sum squared } \\
\text { resid }\end{array}$ & 0.111715 & \multicolumn{2}{|c|}{ Hannan-Quinn crifer. } & -3.399876 \\
\hline $\begin{array}{l}\text { Log } \\
\text { likelihood }\end{array}$ & 114.6704 & \multicolumn{2}{|c|}{ Durbin-Watson stat } & -3.440382 \\
\hline F-statistic & 10.87133 & & & 3.131039 \\
\hline $\begin{array}{ll}\text { Prob } & (\mathrm{F}- \\
\text { statistic }) & \end{array}$ & 0.001608 & & & \\
\hline
\end{tabular}

The Estimation of the first difference model of the Okun equation:

$$
D(G D P)=0.020501-0.188121 D(\text { UNP })
$$

The variables in the equation (4.1) are integrated in order 1 and the residuals have been stationary in the first difference, meaning there is a long-term equilibrium between output and the rate of open unemployment. The coefficient of equation (4.1) -Okun coefficient- is significant at the five percent level significance. Coefficient (-0.188121) indicate that there is a cointegration between real GDP and the rate of open unemployment, so that it can be stated Okun's law exist in the Indonesia's economy.

\section{CONCLUSION}

Okun's law exist in the Indonesia's economy, indicated by a significant Okun's coefficient at first difference model. These results indicate there is a long-term equilibrium between GDP real and the rate of open unemployment. Indonesia's economic growth during 1986-2018 was able to reduce the number of unemployed people in Indonesia.

\section{REFERENCES}

[1] U. Juoro, What do Indonesian economists say about 2018 Indonesia's economic projection? (Apa kata pakar ekonom Indonesia tentang proyeksi ekonomi Indonesia 2018?), 2018, unpublished.

[2] O. Blanchard, Macroeconomics, updated edition, New York: Prentice Hall, Boston, , 2011.

[3] Z.M. Noor, N.M. Nor, and J. Ghani, "The relationship between output and unemployment in Malaysia: does Okun's law exist," International Journal of Economics and Management, vol. 1, no. 3, pp. 337-344. 2007.

[4] D. Darman, "Effect of economic growth on the unemployment rate: Okun's law analysist (Pengaruh pertumbuhan ekonomi terhadap tingkat pengangguran: analisis hukum Okun)," The Winners, vol. 14, no. 1, pp. $1-12,2013$.

[5] T. Gylfason, "Okun's law and labor-market rigidity: the case of Sweden," SNS, 1997.

[6] H. Barreto and F. Howland, There are two Okun's law relationships between output and unemployment, Crawfordsville: Wabash College, 1993.

[7] L. Sögner and A. Stiassny, "An analysis on the structural stability of Okun's law--a cross-country study," Applied Economics, vol. 34, no. 14, pp. 1775-1787, 2002.

[8] Z. M. Noor, N.M. Nor, and J. Ghani, "The relationship between output and unemployment in Malaysia: does Okun's law exist," International Journal of Economics and Management, vol. 1, no. 3, pp. 337-344, 2007.

[9] K. Ahmed, S. Khali, and A. Saeed, "Does There Exist Okun's Law in Pakistan?" International Journal of Humanities and Social Science, vol. 1, no. 12, pp. 293-99, 2011.

[10] S. Sukanto, "Phenomenon of Inflation, Unemployment and Economic Growth in Indonesia: The Philips Curve Approach and the Okun Law, (Fenomena Inflasi, Penganguran Dan Pertumbuhan Ekonomi Di Indonesia: Pendekatan Kurva Philips Dan Hukum Okun)," Journal of Economics \& Development Policy, vol. 13, no. 2, pp. 96-106, 2015. 